\title{
The Mediating Effects of Customer Satisfaction in the Relationship between ATM Service Quality and Customer Loyalty - A Case Study from Bank of Kigali
}

\author{
A. Nshimiyimana
}

\begin{abstract}
The current competition from both national and international markets has created a new assignment for companies to give serious consideration to providing a high quality of service to satisfy and maintain customers. This paper aimed to analyze the mediating effects of customer satisfaction in the relationship between ATM service quality and customer loyalty. The Bank of Kigali has been chosen as case in this research. For this investigation, primary data was collected from 364 respondents from Bank of Kigali's customers through a structured questionnaire. Collected data were analyzed with SPSS (Statistical Package for the Social Sciences, 23.0) according to the objectives of the present research. Results of the descriptive statistics analysis indicated that the age group of 25-34 dominates with $61 \%$ of total respondents, and males showed dominance in terms of gender with $75 \%$ and $55.8 \%$ of respondents were graduates. The study reveals that there is a significant and positive relationship observed between ATM service quality and customer loyalty. This study results have declared that customer satisfaction has positive and significant effect on customer loyalty. Finally, the current research confirmed that there are positive and significant effects of customer satisfaction as mediator in the relationship between ATM service quality dimensions (responsiveness, assurance, and tangibles) and customer loyalty. Therefore, the Bank of Kigali must maximize the quality of services offered to its customers through ATMs to create a good brand image and gain loyalty from users.
\end{abstract}

Keyword - Automated Teller Machine, Service Quality, Customer Satisfaction, Customer Loyalty, Bank of Kigali (BK).

\section{INTRODUCTION}

The financial sector is currently facing a high level of competition between financial services providers and the ever-evolving technology sector. The Banking industry of the 21st century operates in a complex and competitive environment characterized by changing conditions of the business environment that is extremely dynamic and experience rapid changes as a result of technological improvement, increased awareness and demands banks to serve their customers electronically and highly unpredictable economic climate [1]. To cope with competition in this sector, banks are choosing to increase their customer satisfaction through better service delivery and to choose to use electronic technology to increase their service delivery.

Published on July 12, 2020.

A. Nshimiyimana, Chongqing University of Posts and Telecommunications, China.

(e-mail: nalexis.dec12@gmail.com)
In Rwanda, the Bank of Kigali is one of the largest commercial banks with a large number of customers, branches, and a variety of ways to help customers access services through electronic banking.

Service quality and customer satisfaction are key factors in focusing on all sectors in the development of an institution or company. The service quality is an approach of managing the activities of businesses in such an effective way that their clients will be satisfied [2]. By improving the quality of service and satisfying customers and keeping up with the times due to the increase in technologies used to provide faster and better services, banks are using electronic channels to help them achieve this. The researcher argued that Electronic or Online banking first appeared in 1980 when it was understood as a terminal, keyboard, and TV to access the banking system by using a phone line [3]. Electronic banking used by the Bank of Kigali includes Mobile banking, Internet banking, Telephone banking, and Electronic card. With the electronic card, ATM and Point of Sale (POS) terminals allow customers with a bank card to make a transaction. This is also in line with the Rwandan government's commitment to becoming a cashless economy by 2020 by using electronic means in all government financial transactions according to the National Bank of Rwanda (NBR) Annual Report 2016-2017 and shows that the value of e-transactions ratio to GDP reached $21.09 \%$ in 2016 compared to 2015 where it was $16.5 \%$ [4].

The introduction of electronic banking at the Bank of Kigali is a way to continue to provide better customer service as well as other innovative banking products to meet customer satisfaction and meet customer needs aimed at increasing customer satisfaction and customer loyalty as some of the key factors that shape the future of the company. Customer loyalty has been considered as the final goal of relationships in marketing and constructs include service quality, customer satisfaction, perceived service value, customer trust, and perception of the image identified as its determinants constructs [5]. Customer loyalty is an important factor in every institution especially financial institutions because loyal customers can make or predict the future of Banks or any company (Forecast the future of the institution). Customer loyalty can be directly connected to service quality or indirectly through customer satisfaction.

To enhance the quality provide to the customers, it is necessary to know how they are feeling the present service by conducting research or use other means that can help to identify the improvements needed to be made. The present research is intended to conduct research that analyzes the mediating effects of customer satisfaction in the relationship 
between ATM service quality and customer loyalty. The three ATM service quality dimensions (responsiveness, assurance, and tangibles) have been selected from five SERVPERF model dimensions (reliability, responsiveness, assurance, empathy, and tangibles) after discussion of each dimension's importance in evaluating ATM service quality and the cultural importance.

\section{A. Research objectives}

With the general objective of the current study which is to analyze the effect mediation effects of customer satisfaction in the relationship between automated teller machine service quality and customer loyalty, the following three specific objectives of were considered by researcher:

(a) To analyze the relationship between ATM service quality dimensions and customer loyalty.

(b) To analyze the relationship between ATM service quality dimensions and customer satisfaction.

(c) To analyze the mediating effects of customer satisfaction in the relationship between ATM service quality and customer loyalty.

(d) To provide managerial recommendations based on the findings.

\section{B. Profile of Bank of Kigali (BK)}

Bank of Kigali (BK) is a commercial bank in the Republic of Rwanda and the bank is one of the commercial banks licensed by the National Bank of Rwanda (NBR), the country's banking regulator. Bank of Kigali was started in 1966 to provide commercial banking services to individuals, small businesses, and large corporations [1]. By December $31^{\text {st }}, 2019$ the bank had 68 branches, 94 ATMs, 2233 POS, and 1654 agents [6]. In compliance with revised laws relating to private companies in Rwanda, in 2011 the Bank changed its name from Bank of Kigali S.A to Bank of Kigali Limited and BK Group PLC in 2017 with 3 subsidiary companies namely BK General Insurance, BK TecHouse, and BK Capital.

The BK Group Plc Investor Presentation Q4 \& FY 2019 and Annual Report of 2019 clearly showed the vision, mission, and values of Bank of Kigali [1], [6], [7].

Vision: Bank of Kigali aspires to be the leading provider of the most innovative financial solutions in the region.

Mission: Bank of Kigali (BK) mission is to be the leader in creating value for our stakeholders by providing the best financial services to businesses and individual customers, through motivated and professional staff.

Values: Customer Focus, Integrity, Quality \& Excellence.

\section{LITERATURE REVIEW}

\section{A. Service Quality}

The quality of service is an important factor to consider when a particular institution wants to evaluate how its products or services reach customers. Quality can only be judged in the context of customers' expectations and experience. Its value to the customers which should be the driving force of quality needs to be a dynamic factor responding to change. Service is the one opportunity we have to be better than competitors and make sure our customers return which would mainly be the result of quality service [8].

Al-Maslam, (2015) cited that consumers usually judge price and service quality by the concept of "equity", and then generate their satisfaction or dissatisfaction level. Service quality is an approach to manage business processes to ensure the satisfaction of the customers \& quality in service provided. It works as an antecedent of customer satisfaction [10]. The concept of service quality that quality service is a consideration for customers to fulfill satisfaction and product purchase loyalty [9].

\section{B. Customer Satisfaction}

Customer satisfaction is described as a measure on how product or services supplied by an organization meet customers' expectation and satisfaction is measured through the level of product quality, quality of service provided, the location where the product or service is purchased, and price of the product or service [11]. Customer satisfaction and customer loyalty are topics that have been explored at various times, in different countries and different businesses especially in the areas of banking, ATMs, linear shipping, retail banking, and in general business. Researchers have tried to show the relationship between service quality and customer satisfaction and the relationship between customer satisfaction and customer loyalty [12]-[20]. These researchers found that service quality has a strong relationship with customer satisfaction and may have a direct or indirect relationship to customer loyalty. According to Hsu et al., (2012), customer satisfaction relies directly on managing and monitoring individual service encounters, namely the periods of direct customer interaction with a service. Additionally, the researcher declared that the concept of customer satisfaction has become an important concept in both operational and marketing firms as it can determine the future of a company. Customer satisfaction is important in determining the quality of services, especially for continued purchase intention [22]. Therefore, it is very important to take care of the services we provide in the business to maintain customers and attract new customers all of which can make the company's goals achieved as planned and bring benefits to all parties whether the buyer has got what he wants on time, in a good and fast manner and on the owner of a business as to help it expand and continue to thrive.

\section{Customer Loyalty}

Loyalty is the indication of customer satisfaction and it may be found when the customer receives exceed services compared to the expectations. Loyalty is an important factor in the banking sector as it may create a good relationship with customers of a certain bank and keep working with it in the future. Enhancing customer loyalty has become a popular topic for managers, consultants, and academics. The arguments in support of loyalty are simple to understand. Loyal customers are reported to have higher customer retention rates, commit a higher share of their category spending to the firm, and are more likely to recommend others to become customers of the firm. Loyalty is the commitment of a current customer concerning a particular store, brand, and service provider when there are other 
alternatives that the current customer can choose instead [23].

The level of Customer Satisfaction that exists is what can lead to customer loyalty and loyal customer is important in every business because it can come back to apply for service, recommend a company or institution to others and speak for it when necessary. Depending on the number or level of loyal customers in a particular institution, it may be easier for the owners to know the future and to plan solid action-related plans.

To evaluate service quality, different previous researcher used different model include SERVPERF, SERVQUAL, and so many others. However, other researchers criticized that SERVQUAL is not suitable for all areas and cultural difference can be important factor to be considered before adopting SERVPERQUAL model. Therefore, this study used three service quality dimensions (responsiveness, assurance, and tangibles) from five dimensions of SERVPERF model as independent variables to examine ATM service quality.

\section{CONCEPTUAL FRAMEWORK AND METHODOLOGY}

\section{A. Conceptual Framework}

The conceptual framework that leads to the overall processes of this study has been drawn based on the research objective. And it consists of three variables includes independent (ATM Service quality dimensions include responsiveness, assurance, and tangibles), mediator (customer satisfaction), and dependent variable (customer loyalty).

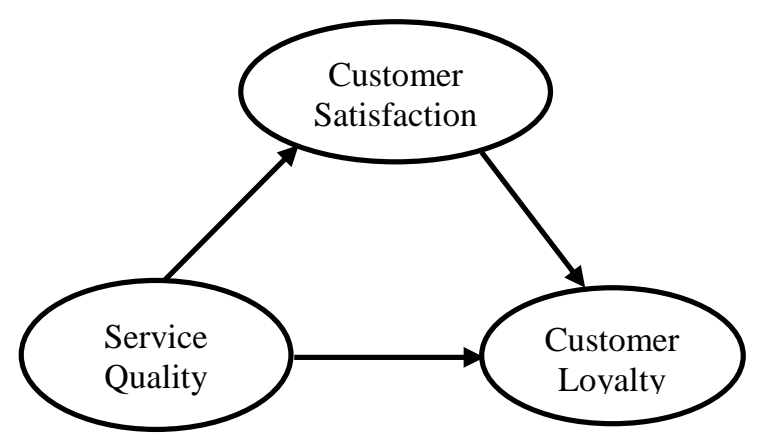

Fig. 1. Conceptual Framework.

Previous studies have identified the importance of the selected three ATM service quality dimensions (responsiveness, assurance, and tangibles) to predicting the satisfaction of customer and customer loyalty.

The following ten hypotheses have proposed by the researcher to be tested in the present study:

Hypotheses of direct effects

H1: Responsiveness has positive effect on customer loyalty.

H2: Assurance has positive effect on customer loyalty.

H3: Tangibles has positive effect on customer loyalty.

Hypotheses of mediation effects

H4: Responsiveness has positive effect on customer satisfaction.

H5: Assurance has positive effect on customer satisfaction.

H6: Tangibles has positive effect on customer satisfaction.

H7: Customer satisfaction has positive effect on customer loyalty.

H8: Customer satisfaction has significant mediating effect in the relationship between responsiveness and customer loyalty.

H9: Customer satisfaction has significant mediating effect in the relationship between assurance and customer loyalty.

H10: Customer satisfaction has significant mediating effect in the relationship between tangibles and customer loyalty.

\section{B. Research Methodology}

Scales and Questionnaire Design: The questionnaire used in this study consists of two main sections; the first section is based on control variables which are designed for collecting personal information (Demographic profile) of the respondents. Control variables and measurements used in this study are including (Age: Under 25, 25 to 34, 35 to 44, 45 to 54, and $55 \&$ above; Gender: Male and Female; Education level: Up to primary school, High school, Graduates, Post-graduates and Other; Monthly income: 050000, 50001-100000, 100001-200000,200001300000,300001-400000,400001-500000,500001 and above).

Section two of the questionnaire comprised 18 statements used to measure the feelings of how strongly disagree/agree about the particular AMT service through independents, intervening, and dependents variables that have been taken by the researcher to conduct a survey. Those statements observed under three dimensions of the SERVPERF model (responsiveness, assurance, and tangibles) as independent variables that used to measure service quality in which 12 items are divided into three components of service quality: Responsiveness (5 items), Assurance 4 items), and Tangibles (3 items). Besides, three items were used to measure mediator (intervening) variables while the remaining three variables (3 items) are used to measure customer loyalty. For rating how customers are strongly disagreeing or strongly agreeing with the statements of variables, the current study used a five-point Likert scale which corresponds values $1=$ Strongly Disagree, 2=Disagree, 3=Neutral, 4=Agree, and 5=Strongly Agree .

\section{Data Collection Techniques}

Both primary and secondary data have been used in this study. Primary data were obtained from the questionnaire administration while secondary data obtained from literature-based research involving an examination of relevant papers from journals, official publications, textbooks, bank records, and other sources on the internet. Trained people collected primary data by providing questionnaires to the Bank's customers from different Bank of Kigali's ATM locations in Kigali city.

\section{DATA ANALYSIS}

A Statistical Package for the Social Sciences (SPSS 23.0) software was used to analyze data from respondents and descriptive statistics of mean and standard deviation, charts, 
and tables were used to present the data.

After receiving the answered questionnaire from respondents, the researcher chooses only useable copies for further analysis and incomplete copies have rejected. A Statistical Package for the Social Sciences (SPSS) version 23.0 was used in the analysis of this study. The 364 useable copies of respondents represent customers of Bank of Kigali which has adopted by research to analyze the mediating effects of customer satisfaction in the relationship between ATM service quality and customer loyalty.

\section{A. Demographic profile of respondents}

The results of demographic profile of customers who have participated in this study are represented in the following Figures (Figure 2, Figure 3, Figure 4, and Figure 5). The figures present Frequency and percent of Age groups, Gender, Education, and Monthly income of 364 respondents.

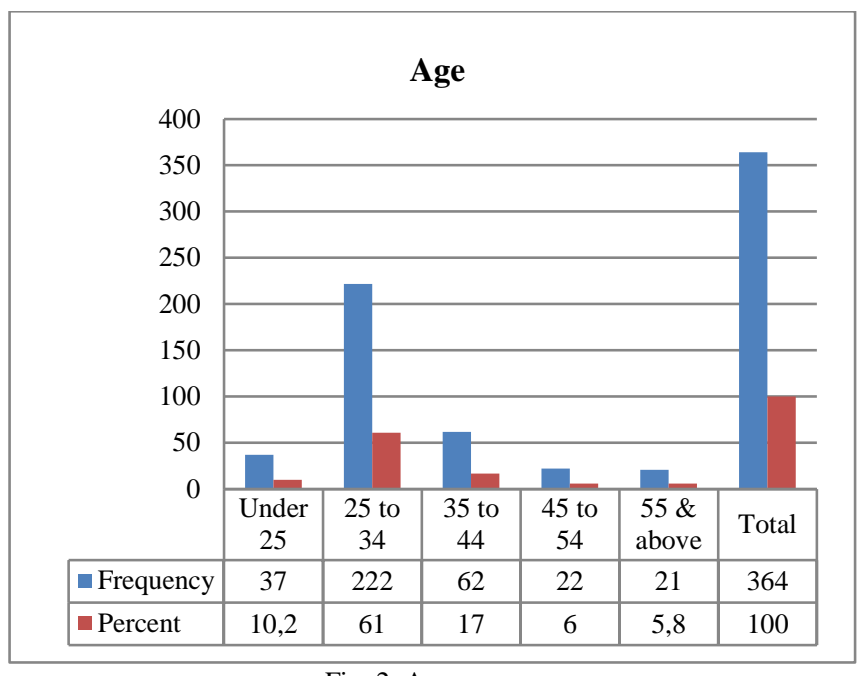

Fig. 2. Age groups.

As it is displayed by Fig. 2 of age groups, the results showed that $61 \%(n=222)$ of respondents are under 25 years, which is the highest portion. It is followed by 35 to 44 years group with $17 \%(n=62)$ and the smallest portion have observed under the age group of $55 \&$ above, which occupied $5.8 \%(n=21)$ of 364 total respondents.

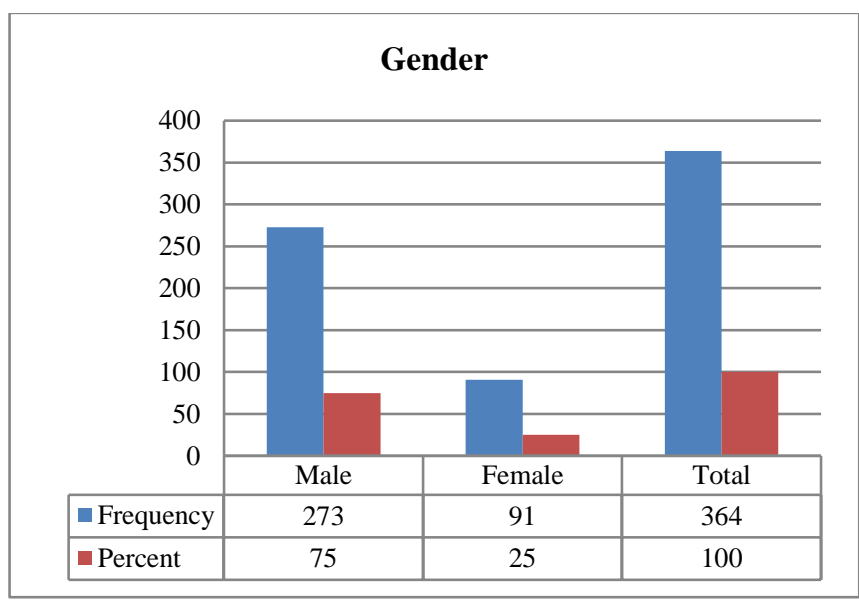

Fig. 3. Gender of respondents.

The result of gender statistics shows that males dominated with $75.0 \%(n=273)$ compared to females who have $91 \%$ $(n=71)$ of the total respondents participated in this study to females who have $25.0 \%(n=71)$ of the respondents.

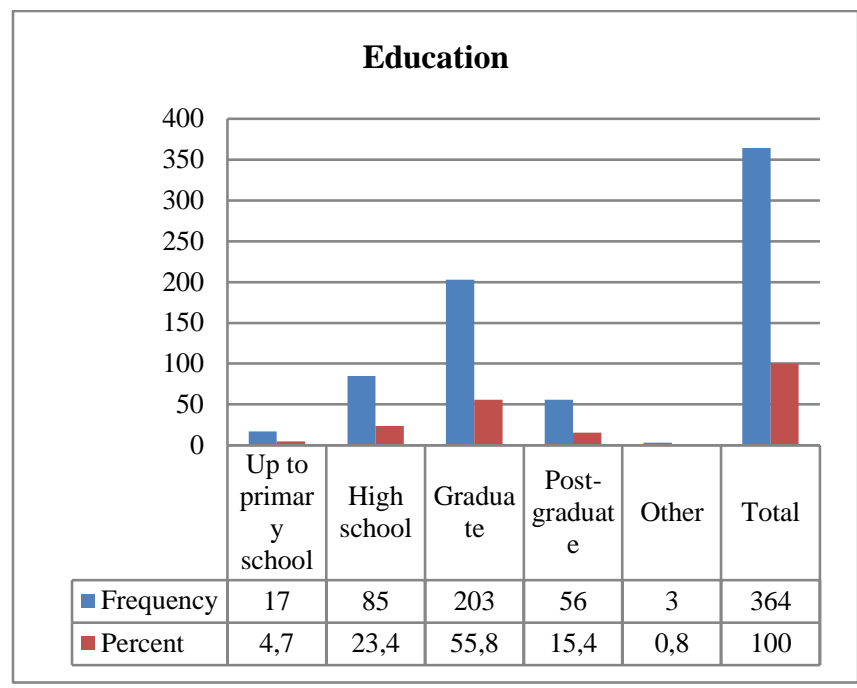

Fig. 4. Education level

Academically, graduate customers constitute $55.8 \%$ ( $\mathrm{n}=$ 203) which is bigger than the total percentage of remaining education categories. Other results for education variable include $23.4 \%(n=85)$ of the customers with high school certificate holders and Post-graduate were $15.4 \%(n=56)$, customers with at least primary school level were $4.7 \%$ ( $=$ $17)$, and others have showed the least portion of $0.8 \%(\mathrm{n}=$ $3)$.

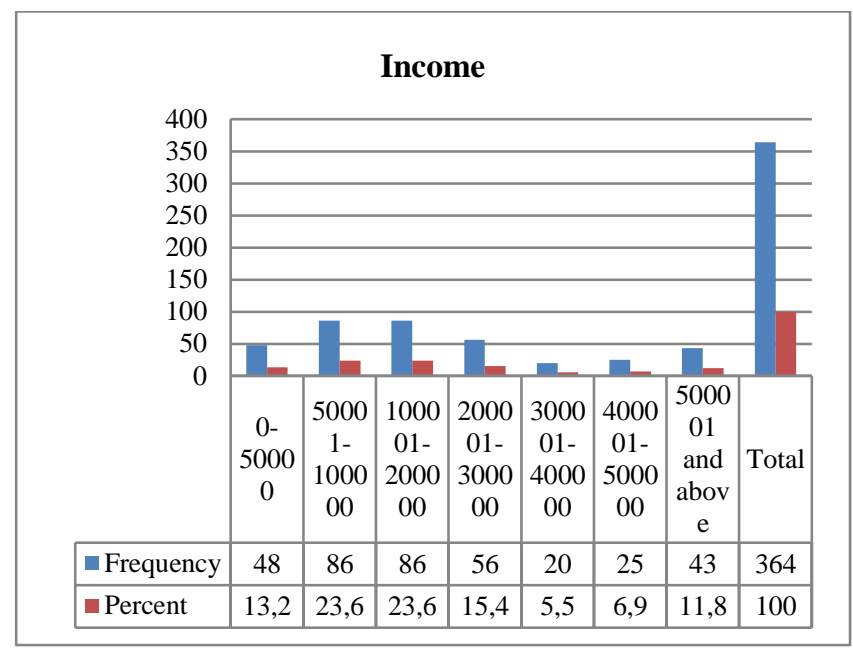

Fig. 5. Monthly Income.

By considering customers' monthly income, it clear that the highest group of participants are observed in the income groups of 50,001-100,000Frw and 100,001-200,000Frw with $(n=86,23.6 \%)$ for each group. The next group is $200,001-300,000$ with $15.4 \%(n=56)$ of the total respondents. The smallest group is observed under 300,001400,000Frw with $5.5 \%(n=20)$.

PS: Frw is the symbol of money currency used in Rwanda.

\section{B. Reliability Analysis}

To apply further analysis for collected data, firstly internal consistency was tested using Cronbach's Alpha coefficient. The results showed that all variables were maintained as they have coefficients alpha greater than 0.7 , 
the value that has been proved by the researcher to be accepted for the next analysis.

Cronbach's Alpha coefficient results of variables are: Responsiveness (0.714), Assurance (0.751), Tangibles (0.711), Satisfaction (0.781 and Loyalty (0.709).

\section{Exploratory Factor Analysis}

Exploratory factor analysis is a statistical technique that used to reduce the number of variables to a smaller set of summary variables and to explore the underlying theoretical structure of the phenomena. It is used to identify the formation of the relationship between the variable and the respondent. The factor extraction and factor rotation are two approaches used to accomplish factor analysis. Prior to the extraction of the factors, several tests should be used to assess the suitability of the respondent data for factor analysis and these tests include Kaiser-Meyer-Olkin (KMO) to measure of Sampling Adequacy and Bartlett's Test of Sphericity.

\section{Kaiser-Meyer - Olkin (KMO) Analysis}

In EFA, the KMO index (Kaiser - Meyer - Olkin) is used to measure the adequacy of responses given with the sample to determine if the response from the sample of the study is adequate or not adequate. KMO values of greater than 0.5 are acceptable. Table 1 shows two tests that indicate the suitability of the data for structure detection. The KaiserMeyer-Olkin Measure of Sampling Adequacy is a statistic that indicates the proportion of variance in the variables that might be caused by underlying factors.KMO values between 0.8 and 1 indicate the sampling is adequate. Kaiser-MeyerOlkin Measure of Sampling Adequacy is 0.830. Therefore, the responses from the sample are adequate. And Bartlett's test of sphericity tests is significant with a significance level of 0.000 (less than 0.001). Thus, the results suggesting that factor analysis is appropriate for the data.

TABLE 1: KMO AND BARTLETT'S TEST

Kaiser-Meyer-Olkin Measure of Sampling Adequacy. Bartlett's Test of Sphericity 0.830
Approx. Chi-Square

3941.795

325

0.000

2. Total Variance Explained in the 5-component PCA

Remember that the Eigenvalue represents the total amount of variance that can be explained by a given principal component. Starting from the first component, each subsequent component is obtained from partially out of the previous component. Therefore, the first component explains the most variance, and the last component explains the least. Looking at the Total Variance Explained table, the total variance explained by each component is displayed. For example, Component 1 is 5.676 , or $(5.676 / 18) \%=$ $(5.676 / 18) * 100=31.534 \%$ of the total variance.

The Total Variance Explained table shows how the variance is divided among the 18 possible factors. Note that five factors have eigenvalues (a measure of explained variance) greater than 1.0, which is a standard criterion for a factor to be useful. When the eigenvalue is less than 1.0, the factor explains less information than a single item would have explained. The Total variance explained of five iterations is significant $63.381 \%$. Therefore, this EFA model is significant, and this can be confirmed by the Scree Plot, which plots the eigenvalue (total variance explained) by the component number.

TABLE 2: TOTAL VARIANCE EXPLAINED

\begin{tabular}{|c|c|c|c|c|c|c|}
\hline \multirow{2}{*}{$\begin{array}{l}\text { Co } \\
\text { mpo } \\
\text { nent }\end{array}$} & \multicolumn{3}{|c|}{ Initial Eigenvalues } & \multicolumn{3}{|c|}{$\begin{array}{c}\text { Extraction Sums of Squared } \\
\text { Loadings }\end{array}$} \\
\hline & Total & $\begin{array}{c}\% \text { of } \\
\text { Variance }\end{array}$ & $\begin{array}{l}\text { Cumul } \\
\text { ative } \%\end{array}$ & Total & $\begin{array}{c}\% \text { of } \\
\text { Variance }\end{array}$ & $\begin{array}{c}\text { Cumula } \\
\text { tive } \%\end{array}$ \\
\hline 1 & 5.676 & 31.534 & 31.534 & 5.676 & 31.534 & 31.534 \\
\hline 2 & 2.288 & 12.713 & 44.247 & 2.288 & 12.713 & 44.247 \\
\hline 3 & 1.229 & 6.825 & 51.072 & 1.229 & 6.825 & 51.072 \\
\hline 4 & 1.187 & 6.592 & 57.664 & 1.187 & 6.592 & 57.664 \\
\hline 5 & 1.029 & 5.717 & 63.381 & 1.029 & 5.717 & 63.381 \\
\hline 6 & 0.847 & 4.704 & 67.528 & & & \\
\hline 7 & 0.758 & 4.209 & 71.737 & & & \\
\hline 8 & 0.606 & 3.367 & 75.104 & & & \\
\hline 9 & 0.597 & 3.318 & 78.422 & & & \\
\hline 10 & 0.571 & 3.171 & 81.593 & & & \\
\hline 11 & 0.530 & 2.947 & 84.540 & & & \\
\hline 12 & 0.497 & 2.760 & 87.300 & & & \\
\hline 13 & 0.455 & 2.526 & 89.826 & & & \\
\hline 14 & 0.425 & 2.363 & 92.189 & & & \\
\hline 15 & 0.403 & 2.239 & 94.428 & & & \\
\hline 16 & 0.397 & 2.206 & 96.634 & & & \\
\hline 17 & 0.374 & 2.078 & 98.712 & & & \\
\hline 18 & 0.232 & 1.288 & 100 & & & \\
\hline
\end{tabular}

Extraction Method: Principal Component Analysis.

\section{Scree Plot}

The scree plot orders the eigenvalues from largest to smallest. The ideal pattern is a steep curve, followed by a bend, and then a straight line. The first component will always have the highest total variance, and the last element will always have the least, but where do we see the most significant drop? If you look at Component 5 (in red color), there is an "elbow" joint. This is the marking point where it's perhaps not too beneficial to continue further component extraction. Using the scree plot author picks five components from the total of 18 components displayed.

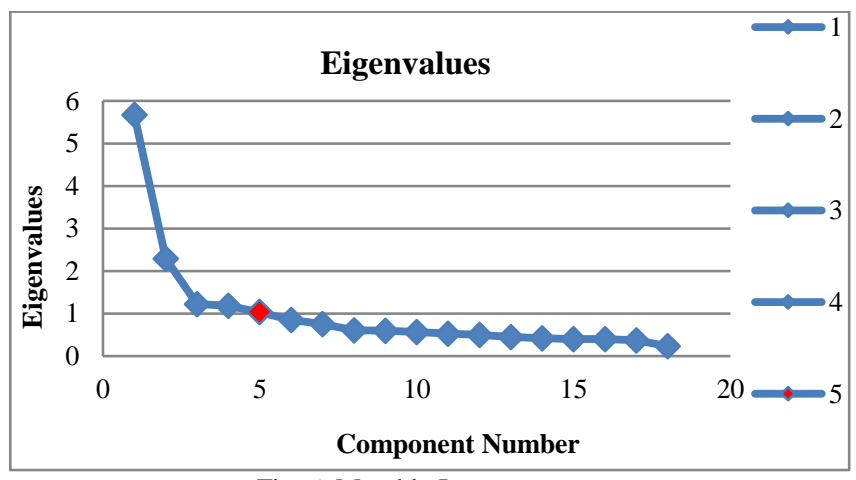

Fig. 6. Monthly Income.

\section{Rotated Component Matrix}

The Rotated Component Matrix table is critical for understanding the results of the analysis. Factors are rotated 
so that they are easier to interpret. Rotation makes it so that, as much as possible, different items are explained or predicted by various underlying factors, and each factor explains more than one item. This is a condition called simple structure.

With the rotated component matrix, eighteen variables were rotated using the Varimax rotation with Kaiser Normalization. Note that the analysis has sorted the 18 math attitude questions (S1 to LOY3) into five somewhat overlapping groups of items. The items are sorted so that the items that have the highest loading from factor 1 (three items in this analysis) are listed first, and they are sorted from the one with the highest factor weight or loading (i.e., T1, with the loading of .733) to the one with the lowest loading from that first factor (T3, with the loading of .661). And this process is applied to other factors.

Based on the result of the Rotated Component Matrix from Table 3, the first three variables loaded highly on factor 1 and were all related to "Tangibles". This factor included items T1, T2, and T3 with loading coefficients respectively equal to $0.733,0.694$, and 0.661 .

The second factor has four variables which were all related to "Assurance" this factor includes A1, A2, A3, and A4 with loading coefficients respectively equal to 0.844 , $0.806,0.794$, and 0.516 .

Factor 3 represents "Responsiveness". This component has five observed variables, including S1, S2, S3, S4, and S5 with loading coefficients greater than 0.5 respectively 0.868 , $0.742,0.672,0.657$ and 0.519 .

Factor 4 represents "loyalty" with three observed variables, including LOY1, LOY2, and LOY3 with loading coefficients greater than 0.7 respectively $0.825,0.767$, and 0.703 .

Factor 5 represents the fifth group of variables and it is related to "Satisfaction". This component has 3 observed variables, including SAT1, SAT2, and SAT3 with loading coefficients greater than 0.6 respectively equal to 0.732 , 0.697 , and 0.675 .

TABLE3: ROTATED COMPONENT MATRIX ${ }^{\mathrm{A}}$

\begin{tabular}{|c|c|c|c|c|c|}
\hline & \multicolumn{5}{|c|}{ Component } \\
\hline & 1 & 2 & 3 & 4 & 5 \\
\hline $\mathrm{S} 1$ & & & 0.868 & & \\
\hline $\mathrm{S} 2$ & & & 0.742 & & \\
\hline S3 & & & 0.672 & & \\
\hline $\mathrm{S} 4$ & & & 0.657 & & \\
\hline S5 & & & 0.519 & & \\
\hline A1 & & 0.844 & & & \\
\hline A2 & & 0.806 & & & \\
\hline A3 & & 0.794 & & & \\
\hline A4 & & 0.516 & & & \\
\hline $\mathrm{T} 1$ & 0.733 & & & & \\
\hline $\mathrm{T} 2$ & 0.694 & & & & \\
\hline $\mathrm{T} 3$ & 0.661 & & & & \\
\hline SAT1 & & & & & 0.732 \\
\hline SAT2 & & & & & 0.697 \\
\hline SAT3 & & & & & 0.675 \\
\hline LOY1 & & & & 0.825 & \\
\hline LOY2 & & & & 0.767 & \\
\hline LOY3 & & & & 0.703 & \\
\hline
\end{tabular}

Extraction Method: Principal Component Analysis.

Rotation Method: Varimax with Kaiser Normalization.

a. Rotation converged in 5 iterations.

\section{Descriptive and Correlation Analysis}

Table 4 displays variables, sample size $(\mathrm{N})$, mean, standard deviation, minimum, and maximum of the used control variables include age, gender, education, and income of the 364 participants.

TABLE 4: DESCRIPTIVE STATISTICS

\begin{tabular}{cccccc}
\hline \hline & & Age & Gender & Education & Income \\
\hline \multirow{2}{*}{$\mathrm{N}$} & Valid & 364 & 364 & 364 & 364 \\
& Missing & 0 & 0 & 0 & 0 \\
Mean & 2.3626 & 1.2500 & 2.8434 & 3.4423 \\
Std. Deviation & 0.95076 & 0.43361 & 0.76435 & 1.85997 \\
Minimum & 1.00 & 1.00 & 1.00 & 1.00 \\
Maximum & 5.00 & 2.00 & 5.00 & 7.00 \\
\hline \hline
\end{tabular}

Table 5 displayed the sample size $(\mathrm{N}=364)$, mean, and standard deviation of the five variables used in the present study. The statistics described the extent to which the sampled respondents strongly agreed or strongly disagreed with the statements used in the questionnaire based on a five-point rating scale from to " 1 " represents "strongly disagree" to " 5 " that represents "strongly agree" with the statement of variables. The results showed that "satisfaction" components have the highest mean of 4.3599. it is followed by "Tangibles" components with mean of 4.3388. Responsiveness components have mean of 4.2165, Loyalty with 4.1529, and Assurance with 4.1374.

TABLE 5: DESCRIPTIVE STATISTICS

\begin{tabular}{cccc}
\hline \hline & Mean & Std. Deviation & $\mathrm{N}$ \\
\hline Loyalty & 4.1529 & 0.54388 & 364 \\
Satisfaction & 4.3599 & 0.58412 & 364 \\
Responsiveness & 4.2165 & 0.48099 & 364 \\
Assurance & 4.1374 & 0.57498 & 364 \\
Tangibles & 4.3388 & 0.54261 & 364 \\
\hline \hline
\end{tabular}

Table 6 represented the correlation results between three ATM service quality dimensions (responsiveness, assurance, and tangibles) with customer satisfaction as mediator and customer loyalty as the dependent variable of this research.

The results showed that customer loyalty has positive and significant correlation with both independent variables and mediator. The results of Pearson correlation between customer loyalty and customer satisfaction, responsiveness, assurance, and tangibles were respectively $0.510,0.491$, 0.438 , and 0.482 with sign. Of 0.000 (p-value $<0.001$ ), Thus, the correlation is two-tailed significant.

Furthermore, the results of the Pearson correlation demonstrated that customer satisfaction had positively and significantly correlated with ATM service quality dimensions.

The results displayed by table 6 clearly showed that all variables are positively and significantly correlated to each other with significant level of 0.000 (2-tailed significant level of 0.001). 
TABLE 6: CORRELATIONS ${ }^{1}$

\begin{tabular}{|c|c|c|c|c|c|c|}
\hline & & LOY & S & A & $\mathrm{T}$ & SAT \\
\hline \multirow[t]{3}{*}{ Loyalty } & $\begin{array}{l}\text { Pearson } \\
\text { Correlation }\end{array}$ & 1 & $.491^{* *}$ & $.438^{* *}$ & $.482^{* *}$ & $.510^{* *}$ \\
\hline & Sig. (2-tailed) & & .000 & .000 & .000 & .000 \\
\hline & $\mathrm{N}$ & 364 & 364 & 364 & 364 & 364 \\
\hline \multirow[t]{3}{*}{$\begin{array}{l}\text { Responsiven } \\
\text { ess }\end{array}$} & $\begin{array}{l}\text { Pearson } \\
\text { Correlation }\end{array}$ & $.491^{* *}$ & 1 & $.506^{* *}$ & $.516^{* *}$ & $.568^{* *}$ \\
\hline & Sig. (2-tailed) & .000 & & .000 & .000 & .000 \\
\hline & $\mathrm{N}$ & 364 & 364 & 364 & 364 & 364 \\
\hline \multirow[t]{3}{*}{ Assurance } & $\begin{array}{l}\text { Pearson } \\
\text { Correlation }\end{array}$ & $.438^{* *}$ & $.506^{* *}$ & 1 & $.576^{* *}$ & $.559^{* *}$ \\
\hline & Sig. (2-tailed) & .000 & .000 & & .000 & .000 \\
\hline & $\mathrm{N}$ & 364 & 364 & 364 & 364 & 364 \\
\hline \multirow[t]{3}{*}{ Tangibles } & $\begin{array}{l}\text { Pearson } \\
\text { Correlation }\end{array}$ & $.482^{* *}$ & $.516^{* * *}$ & $.576^{* * *}$ & 1 & $.648^{* *}$ \\
\hline & Sig. (2-tailed) & .000 & .000 & .000 & & .000 \\
\hline & $\mathrm{N}$ & 364 & 364 & 364 & 364 & 364 \\
\hline \multirow[t]{3}{*}{ Satisfaction } & $\begin{array}{l}\text { Pearson } \\
\text { Correlation }\end{array}$ & $.510^{* *}$ & $.568^{* *}$ & $.559^{* *}$ & $.648^{* *}$ & 1 \\
\hline & Sig. (2-tailed) & .000 & .000 & .000 & .000 & \\
\hline & $\mathrm{N}$ & 364 & 364 & 364 & 364 & 364 \\
\hline
\end{tabular}

**. Correlation is significant at the 0.01 level (2-tailed).

\section{E. Regression Analysis}

The current study is conducted to analyze the mediating effects of customer satisfaction in the relationship between ATM service quality and customer loyalty using SERVPERF model dimensions (Responsiveness, Assurance, and Tangible). Therefore, the regression analysis has undertaken two major processes to analyze the relationship between ATM service quality and customer loyalty (analysis of direct effect) and the analysis of mediation effects which analyzed the relationship between independent variables and mediator, relationship between mediator and dependent variable, and final analyze the effect of mediator in the relationship between independent variables, and customer loyalty.

\section{Regression Analysis of direct effects}

The purpose of regression analysis of direct effects is to test the relationship between independent variables and dependent variable when mediator is excluded in the model. The table below displays the result of the model summary, which indicates that the predictors (constant) variables include responsiveness, assurance, and tangibles while dependent variable is customer loyalty. The value of $R$ indicates that the model is perfectly fitted and fitness of all research questions of independent variables and dependent variables are quit relate to each other.

From Table 7, it can be seen that the $\mathrm{R}$ values is .671 and $\mathrm{R}$ Square value for the model is .526 which explain that 52.6 $\%$ of the variance in the model could be predicted from the three independent variables (tangibles, responsiveness, and assurance).

TABLE 7: MODEL SUMMARY ${ }^{\mathrm{B}}$

\begin{tabular}{cccccc}
\hline \hline Model & $\mathrm{R}$ & R Square & $\begin{array}{c}\text { Adjusted R } \\
\text { Square }\end{array}$ & $\begin{array}{c}\text { Std. Error of } \\
\text { the Estimate }\end{array}$ & $\begin{array}{c}\text { Durbin- } \\
\text { Watson }\end{array}$ \\
\hline 1 & $0.671^{\mathrm{a}}$ & 0.526 & 0.520 & 0.64847 & 2.053 \\
\hline \hline
\end{tabular}

The following Table 8 displayed the results of ANOVA test on the general significance of the model. It is clear that the model is significant with a p-value below 0.05 . Thus, the components of tangibles, responsiveness, and assurance significantly predict the dependent variable (customer loyalty) with F3=57.955 and p-value $=0.000(\mathrm{p}<0.05)$.

TABLE 8: ANOVA $^{\mathrm{A}}$

\begin{tabular}{ccccccc}
\hline \hline Model & $\begin{array}{c}\text { Sum of } \\
\text { Squares }\end{array}$ & df & $\begin{array}{c}\text { Mean } \\
\text { Square }\end{array}$ & F & Sig. \\
\hline \multirow{2}{*}{1} & Regression & 34.970 & 3 & 11.657 & 57.955 & $0.000^{\mathrm{b}}$ \\
& Residual & 72.406 & 360 & 0.201 & & \\
& Total & 107.376 & 363 & & & \\
\hline \hline
\end{tabular}

a. Dependent Variable: Loyalty.

b. Predictors: (Constant), Tangibles, Responsiveness, Assurance.

The standardized Coefficients Beta and significance level of variables displayed by Table 8 showed that responsiveness, assurance, and tangible are significant. Thus, the three dimensions of service quality of the automated teller machine have significant effect on customer loyalty. If $0<\mathrm{VIF}<10$, means that collinearity is not significant. Therefore, this model demonstrates that there is no collinearity.

The coefficient analysis displayed by Table 8 showed that responsiveness has a coefficient beta of 0.288 , with significant value $=0.000(\mathrm{p}<0.05)$, assurance has a coefficient beta of 0.150 , with significant value $=0.007$ ( $\mathrm{p}<$ 0.05 ) and tangibles have coefficient beta and significant value 0.247 and $0.000(\mathrm{p}<0.05)$ respectively. Thus, responsiveness, assurance, and tangibles have significant effects on customer loyalty. Therefore, the study confirms the significance of hypotheses $(\mathrm{H} 1, \mathrm{H} 2$, and $\mathrm{H} 3)$ based on the results.

TABLE 9: COEFFICIENTS ${ }^{\mathrm{A}}$

\begin{tabular}{|c|c|c|c|c|c|c|c|}
\hline \multirow[b]{2}{*}{ Model } & \multicolumn{2}{|c|}{$\begin{array}{l}\text { Unstandardize } \\
\text { d Coefficients }\end{array}$} & $\begin{array}{l}\text { Standa } \\
\text { rdized } \\
\text { Coeffi } \\
\text { cients } \\
\end{array}$ & \multirow[b]{2}{*}{$\mathrm{t}$} & \multirow[b]{2}{*}{ Sig. } & \multicolumn{2}{|c|}{$\begin{array}{c}\text { Collinearity } \\
\text { Statistics }\end{array}$} \\
\hline & $\mathrm{B}$ & $\begin{array}{l}\text { Std. } \\
\text { Error }\end{array}$ & Beta & & & $\begin{array}{l}\text { Toler } \\
\text { ance }\end{array}$ & VIF \\
\hline 1 (Constant) & 1.121 & 0.232 & & 4.839 & 0.000 & & \\
\hline $\begin{array}{l}\text { Responsive } \\
\text { ness }\end{array}$ & 0.325 & 0.060 & 0.288 & 5.435 & 0.000 & 0.669 & 1.496 \\
\hline Assurance & 0.142 & 0.052 & 0.150 & 2.709 & 0.007 & 0.609 & 1.642 \\
\hline Tangibles & 0.247 & 0.056 & 0.247 & 4.413 & 0.000 & 0.600 & 1.666 \\
\hline
\end{tabular}

a. Dependent Variable: Loyalty

\section{Regression Analysis of mediation test}

(1) Test between independent variables and mediator

The following table 10 displays the results of the model summary, which indicates that the predictors (constant) variables include tangibles, responsiveness, and assurance while mediator variable (customer satisfaction) are taken as dependent variable. From Table 10, it can be seen that the $\mathrm{R}$ Square value for the model showed $61.7 \%$ of the variance in the model can be predicted from the three independent variables (tangibles, responsiveness, and assurance).

TABLE 10: MODEL SUMMARY ${ }^{\mathrm{B}}$

\begin{tabular}{llrrrr} 
Model & R & R Square & $\begin{array}{c}\text { Adjusted R } \\
\text { Square }\end{array}$ & $\begin{array}{c}\text { Std. Error of } \\
\text { the Estimate }\end{array}$ & $\begin{array}{c}\text { Durbin- } \\
\text { Watson }\end{array}$ \\
\hline 1 & $.719^{\text {a }}$ & .617 & .613 & .50753 & 1.975 \\
\hline \hline
\end{tabular}


a. Predictors: (Constant), Tangibles, Responsiveness, Assurance

b. Dependent Variable: Satisfaction.

The following Table 11 gives the ANOVA test on the general significance of the model. As $\mathrm{p}$ is less than 0.05 , the model is significant. Thus, the tangibles, responsiveness, and assurance significantly predict the dependent variable (customer satisfaction) with F3 $=128.581$ and $\mathrm{p}=0.000$, $(\mathrm{p}$ $<0.05)$.

TABLE 11: ANOVA $^{\mathrm{A}}$

\begin{tabular}{ccccccc}
\hline \hline \multirow{2}{*}{ Model } & $\begin{array}{c}\text { Sum of } \\
\text { Squares }\end{array}$ & df & $\begin{array}{c}\text { Mean } \\
\text { Square }\end{array}$ & F & \multirow{2}{*}{ Sig. } \\
\hline \multirow{4}{*}{1} & Regression & 64.065 & 3 & 21.355 & 128.581 & $0.000^{\mathrm{b}}$ \\
& Residual & 59.790 & 360 & 0.166 & & \\
& Total & 123.854 & 363 & & & \\
\hline \hline
\end{tabular}

a. Dependent Variable: Satisfaction.

b. Predictors: (Constant), Tangibles, Responsiveness, Assurance.

By considering each component from Table 12, responsiveness has a coefficient beta of 0.262 with significant value of $0.000 \quad(\mathrm{p}<0.05)$. Thus, the responsiveness component has a significant effect on customer satisfaction. Similarly, the standardized coefficient beta of assurance and tangibles components are 0.197 and 0.399 respectively with Sig. $=0.000(p<0.05)$. Therefore, assurance and tangibles components have a significant effect on dependent variable (customer satisfaction). H6).

Thus, the study accepts three hypotheses (H4, H5, and

\section{TABLE 11: COEFFICIENTS ${ }^{\mathrm{A}}$}

\begin{tabular}{|c|c|c|c|c|c|c|c|}
\hline \multirow{2}{*}{ Model } & \multicolumn{3}{|c|}{$\begin{array}{cc} & \text { Standar- } \\
\text { lized } & \text { dized } \\
\text { nts } & \text { Coeffi- } \\
& \text { cients } \\
\end{array}$} & \multirow{2}{*}{$\mathrm{t}$} & \multirow{2}{*}{ Sig. } & \multicolumn{2}{|c|}{$\begin{array}{c}\text { Collinearity } \\
\text { Statistics }\end{array}$} \\
\hline & B & $\begin{array}{l}\text { Std. } \\
\text { Error }\end{array}$ & Beta & & & $\begin{array}{l}\text { Tole- } \\
\text { rance }\end{array}$ & VIF \\
\hline (Constant) & 0.326 & 0.211 & & 1.550 & 0.122 & & \\
\hline $\begin{array}{c}\text { Responsive } \\
\text { ness }\end{array}$ & 0.319 & 0.054 & 0.262 & 5.860 & 0.000 & 0.669 & 1.496 \\
\hline Assurance & 0.200 & 0.048 & 0.197 & 4.194 & 0.000 & 0.609 & 1.642 \\
\hline Tangibles & 0.429 & 0.051 & 0.399 & 8.437 & 0.000 & 0.600 & 1.666 \\
\hline
\end{tabular}

a. Dependent Variable: Satisfaction/

(2) Test between mediator and dependent variable

The Table 13 displays the result of the model summary, which indicates that the constant variable customer satisfaction is taken. The values of $\mathrm{R}$ and $\mathrm{R}$ Square demonstrate that the model is perfectly fitted and fitness of all research questions of mediator variable and dependent variable are quite related to each other. Table 13 of the model summary indicates that $\mathrm{R}$ equals 0.830 and $\mathrm{R}$ square value is 0.760 which showed that 76 percent of the variance in the model can be predicted by customer satisfaction.

TABLE 13: MODEL SUMMARY ${ }^{\mathrm{B}}$

\begin{tabular}{lcrrrr}
\hline \hline Model & $\mathrm{R}$ & $\mathrm{R}$ Square & $\begin{array}{c}\text { Adjusted R } \\
\text { Square }\end{array}$ & $\begin{array}{c}\text { Std. Error of } \\
\text { the Estimate }\end{array}$ & $\begin{array}{c}\text { Durbin- } \\
\text { Watson }\end{array}$ \\
\hline 1 & $0.810^{\mathrm{a}}$ & 0.760 & 0.758 & 0.86836 & 2.142 \\
\hline \hline
\end{tabular}

a. Predictors: (Constant), Satisfaction.

b. Dependent Variable: Loyalty.
Table 14 of ANOVA test presents the overall significance of the regression model in terms of goodness of fit between customer satisfaction and loyalty in Bank of Kigali. The model is significant at a p-value of (0.000) which is accepted value as it is below the significance value of 0.05 . Thus, the satisfaction of customers significantly predicts the dependent variable customer loyalty with F1 $=127.497$ and $\mathrm{p}<0.05$.

TABLE 14: ANOVA $^{\mathrm{A}}$

\begin{tabular}{|c|c|c|c|c|c|c|}
\hline & Model & $\begin{array}{l}\text { Sum of } \\
\text { Squares }\end{array}$ & df & $\begin{array}{c}\text { Mean } \\
\text { Square }\end{array}$ & $\mathrm{F}$ & Sig. \\
\hline \multirow{3}{*}{1} & Regression & 27.968 & 1 & 27.968 & 127.497 & $0.000^{\mathrm{b}}$ \\
\hline & Residual & 79.408 & 362 & 0.219 & & \\
\hline & Total & 107.376 & 363 & & & \\
\hline
\end{tabular}

Table 14 determines that customer satisfaction has a significant effect on customer loyalty with the values of standardized coefficients beta and significance level of 0.510 and sig. $=0.000, \mathrm{p}<0.05)$ respectively. Therefore, the results of this study showed that hypothesis seven $(\mathrm{H} 7)$ is accepted.

TABLE 15: COEFFICIENTS ${ }^{\mathrm{A}}$

\begin{tabular}{|c|c|c|c|c|c|c|c|}
\hline \multirow[b]{2}{*}{ Model } & \multicolumn{3}{|c|}{$\begin{array}{cc} & \text { Standar- } \\
& \text { dized } \\
\text { Unstandardized } & \text { Coeffi- } \\
\text { Coefficients } & \text { cients } \\
\end{array}$} & \multirow[b]{2}{*}{$\mathrm{t}$} & \multirow[b]{2}{*}{ Sig. } & \multicolumn{2}{|c|}{$\begin{array}{c}\text { Collinearity } \\
\text { Statistics }\end{array}$} \\
\hline & B & $\begin{array}{l}\text { Std. } \\
\text { Error }\end{array}$ & Beta & & & $\begin{array}{l}\text { Tole- } \\
\text { rance }\end{array}$ & VIF \\
\hline 1 (Constant) & 2.081 & 0.185 & & 11.242 & 0.000 & & \\
\hline Satisfaction & 0.475 & 0.042 & 0.510 & 11.291 & 0.000 & 1.000 & 1.000 \\
\hline
\end{tabular}

a. Dependent Variable: Loyalty

(3) Test between independent variables, mediator and dependent variable

The purpose of this analysis is to analyze the change in total effect of relationship between independent variables (responsiveness, assurance, and tangibles) and dependent variable (customer loyalty) when mediator variable (customer satisfaction) is included in the model.

The following Table 16 displays the result of the model summary which indicates that responsiveness, assurance, tangibles and satisfaction are predictors and customer loyalty is dependent variable. The values of $\mathrm{R}$ and $\mathrm{R}$ square are respectively 0.790 and 0.648 .

The finding of R Square value for the model explains that $64.8 \%$ of the variance in the model can be predicted from the satisfaction.

TABLE 16: MODEL SUMMARY ${ }^{\mathrm{B}}$

\begin{tabular}{cccccc}
\hline \hline $\begin{array}{c}\text { Mode } \\
1\end{array}$ & $\mathrm{R}$ & $\begin{array}{c}\mathrm{R} \\
\text { Square }\end{array}$ & $\begin{array}{c}\text { Adjusted R } \\
\text { Square }\end{array}$ & $\begin{array}{c}\text { Std. Error of } \\
\text { the Estimate }\end{array}$ & $\begin{array}{c}\text { Durbin- } \\
\text { Watson }\end{array}$ \\
\hline 1 & $0.790^{\mathrm{a}}$ & 0.648 & 0.641 & 0.64166 & 2.104 \\
\hline \hline
\end{tabular}

a. Predictors: (Constant), Tangibles, Responsiveness, Assurance, Satisfaction.

b. Dependent Variable: Loyalty.

The ANOVA test results showed that the model is significant, with a $\mathrm{p}$-value of 0.000 ( $\mathrm{Sig}=0.000, \mathrm{p}<0.05)$. Thus, the customer satisfaction, responsiveness, assurance, 
and tangibles significantly predicts customer loyalty with F4 $=47.865$ and sig. of $0.000(\mathrm{p}<0.05)$.

TABLE 17:ANOVA ${ }^{\mathrm{A}}$

\begin{tabular}{ccccccc}
\hline \hline \multirow{2}{*}{ Model } & $\begin{array}{c}\text { Sum of } \\
\text { Squares }\end{array}$ & df & $\begin{array}{c}\text { Mean } \\
\text { Square }\end{array}$ & F & \multirow{2}{*}{ Sig. } \\
\hline \multirow{4}{*}{1} & Regression & 37.347 & 4 & 9.337 & 47.865 & $0.000^{\mathrm{b}}$ \\
& Residual & 70.029 & 359 & 0.195 & & \\
& Total & 107.376 & 363 & & & \\
\hline \hline
\end{tabular}

a. Dependent Variable: Loyalty.

b. Predictors: (Constant), Tangibles, Responsiveness, Assurance, Satisfaction.

When mediator variable (customer satisfaction) used in the model, the coefficient analysis displayed by Table 18 showed that satisfaction has a standardized coefficient beta of 0.214 with significant value $=0.001(\mathrm{p}<0.05)$, responsiveness has standardized coefficient beta of 0.231 and significant value ( $\mathrm{sig} .=0.000 \mathrm{p}<0.05$ ), assurance has standardized coefficient beta of 0.108 and significant value (sig. $=0.054 \mathrm{p}>0.05)$, and tangibles have standardized coefficient beta of 0.161 and significant value ( $\mathrm{sig}$. $=0.008$ $\mathrm{p}<0.05)$.

\section{TABLE 18: COEFFICIENTS ${ }^{\mathbf{A}}$}

\begin{tabular}{|c|c|c|c|c|c|c|c|c|}
\hline & \multirow{2}{*}{ Model } & \multirow{2}{*}{\multicolumn{3}{|c|}{$\begin{array}{lc}\text { lized } & \begin{array}{c}\text { Standar- } \\
\text { dized } \\
\text { nts } \\
\text { Coeffi- } \\
\text { cients }\end{array} \\
\text { td. } \\
\text { rror } & \text { Beta } \\
\end{array}$}} & \multirow{2}{*}{$\mathrm{t}$} & \multirow{2}{*}{ Sig. } & \multicolumn{2}{|c|}{$\begin{array}{l}\text { Collinearity } \\
\text { Statistics }\end{array}$} \\
\hline & & & & & & & $\begin{array}{l}\text { Tole- } \\
\text { rance }\end{array}$ & VIF \\
\hline \multirow{5}{*}{1} & (Constant) & 1.056 & 0.229 & & 4.613 & 0.000 & & \\
\hline & Satisfaction & 0.199 & 0.057 & 0.214 & 3.491 & 0.001 & 0.483 & 2.072 \\
\hline & $\begin{array}{l}\text { Responsi- } \\
\text { veness }\end{array}$ & 0.262 & 0.062 & 0.231 & 4.243 & 0.000 & 0.610 & 1.638 \\
\hline & Assurance & 0.102 & 0.053 & 0.108 & 1.933 & 0.054 & 0.581 & 1.722 \\
\hline & Tangibles & 0.161 & 0.060 & 0.161 & 2.676 & 0.008 & 0.501 & 1.995 \\
\hline
\end{tabular}

a. Dependent Variable: Loyalty.

By comparing the results from analysis of direct effects between independent variables and dependent variable without mediator in the model and analysis of when mediation included in the model, it is clear that there are changes in reduction of standardized coefficients beta for all independent variables. Without mediator in the model, Table 9 indicates that the standardized coefficients beta of responsiveness, assurance, and tangibles equals 0.288 , 0.150 , and 0.247 respectively. With mediator, Table 18 shows that the standardized coefficients beta of responsiveness, assurance, and tangibles equals 0.231 , 0.108 , and 0.161 respectively. Thus, the results showed that hypotheses H8, H9, and H10 are accepted by the results of current research. Responsiveness and tangibles are partially mediated by customer satisfaction. Therefore, the partial mediation effect found from $\mathrm{H} 8$ and $\mathrm{H} 10$ with significant path while complete mediation effect has observed on H9 of the study with non-significant path ( $p$-value $=0.054, p>0.05$ ).

Thus, the current study confirmed that customer satisfaction mediate the relationship between ATM service quality and customer loyalty. Therefore, it is agreed that Customer satisfaction has a significant mediating effect in the relationship between responsiveness, assurance and tangibles and customer loyalty.

\section{DISCUSSION AND CONCLUSION}

With the aims of analyzing the mediating effects of customer satisfaction in the relationship between ATM service quality and customer loyalty, the present study has conducted in Bank of Kigali, and 364 responses of customers participated in the current research were used to analyze their rating on provided measurements of variables adopted by the researcher.

The results from demographic profile of the present research showed that in terms of age, more than half of the total respondents presented by the age group of 25 to 34 years old with portion of $61 \%$ and it is followed by group of 35 to 44 years old with $17 \%$. The percentage of $75 \%$ $(n=273)$ represents the dominance of males in this study. By considering education level, graduates customers determined to be dominant with $55.8 \%$ of the total number of respondents and it is followed by customers with high school certificates that occupied $23.4 \%$. And the participant's monthly income showed that customers with $50,001-100,000$ present $23.6 \%$ of total participants and this same as participants with monthly income of 100,000200,000 Frw as they also showed to be $23.6 \%$. And they are followed by group of customers with monthly income of $200,001-300,000$ that have $15.4 \%$ of total participants. The descriptive statistics results reveal that all five variables have mean tend to four (Agree) which means that respondents are about to support all measurements' statements with Agree.

The analysis of internal consistency and validity have confirmed the appropriate of variables for further analysis as they showed to have acceptable values of Cronbach Alpha's coefficients for reliability analysis and KMO and analysis, Bartlett's Test of Sphericity confirmed the adequacy and signicance of the responses from the sample of the study. Therefore, the variables have accepted to be used for further analysis.

Correlation results showed that customer loyalty positively and significantly correlated with ATM service quality dimensions used in this study (responsiveness, assurance, and tangibles), and customer satisfaction. The correlation analysis also showed that customer satisfaction correlated with all variables significantly.

By conducting regression analysis, the first analysis was to assess the relationship between responsiveness, assurance, and tangibles and customer loyalty. The results determined that SERVPERF dimensions of service quality, (responsiveness, assurance, and tangible) have positive and significant effects on customer loyalty. And from these results, research accepted three hypotheses including $\mathrm{H} 1$, $\mathrm{H} 2$, and $\mathrm{H} 3$ of the study.

After analyzing the relationship between independent variables and dependent variable when mediator excluded in the model, researcher analyzed the effect of mediation in the model through three processes:

1. test between independent variables and mediator. From this test, the results displayed by table 12 confirmed that there is a positive and significant relationship between independent variables (responsiveness, assurance, and 
tangibles) and mediator variable (customer satisfaction). Thus, the study confirmed and accepted the current research hypothesis $\mathrm{H} 4, \mathrm{H} 5$, and $\mathrm{H} 6$.

2. test between mediator (customer satisfaction) and dependent variable (customer loyalty). The results showed that customer satisfaction has positive and significant effects on customer loyalty and this allowed researcher to accept H7.

3. test between independent variables, mediator, and dependent variable.

By comparing the results from direct effects analysis between independent variables and dependent variable without mediator in the model and analysis when mediation included in the model, it is clear that there are changes in reduction of standardized coefficients beta for all independent variables. Without mediator in the model, Table 9 indicates that the standardized coefficients beta of responsiveness, assurance, and tangibles equals 0.288 , 0.150 , and 0.247 respectively and when mediator used in the model there is reduction of coefficient beta as it is displayed by Table 18. However, the results showed that hypotheses $\mathrm{H} 8, \mathrm{H} 9$, and $\mathrm{H} 10$ are accepted by the results of current research. Responsiveness and tangibles are partially mediated by customer satisfaction. Therefore, the partial mediation effect found from $\mathrm{H} 8$ and $\mathrm{H} 10$ with significant path while complete mediation effect has observed on $\mathrm{H} 9$ of the study with non-significant path ( $p$-value $=0.054, p>0.05$ ).

Thus, the current study confirmed that customer satisfaction mediate the relationship between ATM service quality and customer loyalty. Therefore, it is agreed that Customer satisfaction has a significant mediating effect in the relationship between responsiveness, assurance and customer loyalty.

Previous researchers have found that service quality has a positive and significant effect on customer loyalty and it has been identified as a determinant construct of customer loyalty [5], [24].

The results of this study clearly show that ATM service quality has direct effect on customer loyalty and customer satisfaction and customer satisfaction positively and significantly affect customer loyalty. Furthermore, the study confirmed that customer satisfaction have a positive mediating effect $\mathrm{s}$ in the relationship between ATM service quality dimensions include responsiveness, assurance, and tangibles and customer loyalty. Jaya's research in Oman found that service quality contributes to customer satisfaction with strong and significant linkage and customer satisfaction is also found to lead to behavioral intentions with significant link but that link is weak [16].

So this shows that service quality care is very important in striving to increase and maintain customer satisfaction, especially in the bank through electronic banking as a channel to bring customers closer to the service that saves time and cost.

In a study on Electronic Payment Systems Implementation and the Performance of Commercial Banks in Nigeria, researchers point out that increased use of ATMs will increase in the asset base of banks. While in Rwanda, Harelimana researched the theme of The Automated Teller Machines and Profitability of Commercial Banks in Rwanda, in its research, found that there is a significant relationship between ATMs and the profitability of Banks in Bank of Kigali where they found that the correlation between ROA, ROE, and net margin was above 0.5 . He also pointed out low cost, differentiation, and accessibility as factors that could indicate the level of satisfaction of BK ATM users [25].

Based on the results of this study and the findings of other researchers, it recommended that bank managers should take care of the services provided through ATMs striving to ensure that the customer gets the best service and in the shortest possible time, explain to the customers how to use ATMs card, especially for new ones, increase the services provided by ATMs and having a reliable and fast way to help the customer hunt down the challenges of making a transaction. Advertisement is also important in helping bank managers to encourage customers to use electronic means when they need service to continue to promote the culture of using technology in services as part of the Rwandan government's program.

\section{REFERENCES}

[1] H. Asy’ari, “No Title空間像再生型立体映像の 研究動向,” Nhk技研, vol. 151, no. september 2016, pp. 10-17, 2015.

[2] S. Hajdari, "Service Quality in Higher Education Institutions an Overview of Models Assessing It," Eur. J. Bus. Manag. Res., vol. 4 , no. 3, pp. 1-4, 2019.

[3] H. Khan, M. M. Mir, K. Khan, A. Raza, and E. Khan, "Analysis of Electronic Banking Services \& Its Issues in Pakistan Analysis of Electronic Banking Services \& Its Issues in Pakistan," Eur. J. Bus. Manag., vol. 8, no. December, pp. 0-8, 2016.

[4] T. C. Endangered and S. C. Council, "Annual Report Annual Report,” COSEWIC Annu. Rep., no. June, pp. 2007-2008, 2017.

[5] V. Leninkumar, "The Relationship between Customer Satisfaction and Customer Trust on Customer Loyalty," Int. J. Acad. Res. Bus. Soc. Sci., vol. 7, no. 4, pp. 450-465, 2017.

[6] "Scapa Group plc - Investor Presentation," no. September, pp. 1-46, 2019.

[7] A. Report, "DËiv e " vsK wjwg †UW," 2019.

[8] M. A. Mekonen, Y. Rong, and T. Gebremedhin, "Assessment Of Customer Satisfaction In Banking Services: A Comparison Between State Owned And Private Banks In Axum Town, Ethiopia," Eur. J. Bus. Manag. Res., vol. 4, no. 6, pp. 1-10, 2019.

[9] S. Al-Maslam, "The Relationship between Customer Satisfaction and Customer Loyalty in the Banking Sector in Syria," J. Mark. Consum. Res., vol. 7, p. 9, 2015.

[10] A. Jephthah Kwame, A. Jeremiah Kwaku, and T. Hongyun, "Service Quality and Consumer Choice of Their Preferred Telecommunications Service Provider in Ghana," Eur. J. Bus. Manag. Res., vol. 4, no. 6, pp. 1-9, 2019.

[11] N. Alexis and W. Chen, "To cite this article: Nshimiyimana Alexis, Wenpei Chen. An Empirical Study Analyzing the ATM Service Quality and Customer Satisfaction Relationship in Rwanda," Int. J. Bus. Econ. Res., vol. 8, no. 6, pp. 439-451, 2019.

[12] D. L. Haytko and C. S. Simmers, "What's your preference?: An exploratory examination of the effect of human vs ATM vs online interactions on overall consumer satisfaction with banking services," Manag. Res. News, vol. 32, no. 4, pp. 337-353, 2009.

[13] K. F. Yuen and V. V. Thai, "Service quality and customer satisfaction in liner shipping," Int. J. Qual. Serv. Sci., vol. 7, no. 2-3, pp. 170-183, 2015.

[14] B. Narteh, "Service quality and customer satisfaction in Ghanaian retail banks: the moderating role of price," Int. J. Bank Mark., vol. 36, no. 1, pp. 68-88, 2018.

[15] L. Zhou, "A dimension-specific analysis of performance-only measurement of service quality and satisfaction in China's retail banking," J. Serv. Mark., vol. 18, no. 7, pp. 534-546, 2004.

[16] T. Levesque and G. H. g. Mcdougall, "Determinants of customer satisfaction in retail banking," Int. J. Bank Mark., vol. 14, no. 7, pp. 
12-20, 2016

[17] V. Yilmaz, E. Ari, and H. Gürbüz, "Investigating the relationship between service quality dimensions, customer satisfaction and loyalty in Turkish banking sector: An application of structural equation model," Int. J. Bank Mark., vol. 36, no. 3, pp. 423-440, 2018.

[18] F. Faghani, "c r v i h o e f c r vi h o e f," vol. 2, no. 4, pp. 351-361, 2012.

[19] A. Moustafa and K. Eissa, "Impact of E-service Quality Dimensions on Word-of-Mouth and Customer Retention and the Mediating Role of Customer Satisfaction: A Study on E- commerce in Malaysia," vol. 7, no. 1, 2019.

[20] A. Athanassopoulos, S. Gounaris, and V. Stathakopoulos, "Behavioural responses to customer satisfaction: an empirical study," Eur. J. Mark., vol. 35, no. 5/6, pp. 687-707, 2001.

[21] C. L. Hsu, K. C. Chang, and M. C. Chen, "The impact of website quality on customer satisfaction and purchase intention: Perceived playfulness and perceived flow as mediators," Inf. Syst. E-bus. Manag., vol. 10, no. 4, pp. 549-570, 2012.

[22] H. Khalil, "The Role of the Quality of a Website in Consumer Perception," pp. 1-82, 2017.

[23] H. Rahman, "Customer Satisfaction and Loyalty: A Case Study from the Banking Sector," Cent. Eur. Bus. Rev., vol. 2, no. 4, pp. 15-23, 2013.

[24] D. A. Harahap, R. Hurriyati, , D., V. Gaffar, and D. Amanah, "Service Quality Towards Bank Customer Loyalty (Empirical Study at BNI USU Medan)," Eur. J. Bus. Manag. Res., vol. 4, no. 5, pp. 1$6,2019$.

[25] J. B. Harelimana, "The Automated Teller Machines and Profitability of Commercial Banks in Rwanda," vol. 18, no. 1, 2018.

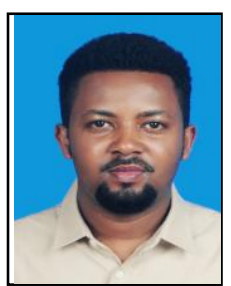

NSHIMIYIMANA Alexis earned a bachelor of technology in Information and Communication Technology (ICT) in 2015 from the University of Rwanda (UR), Rwanda. Currently, I am completing a master's degree in Management Science and Engineering at Chongqing University of Posts and Telecommunications, China. 